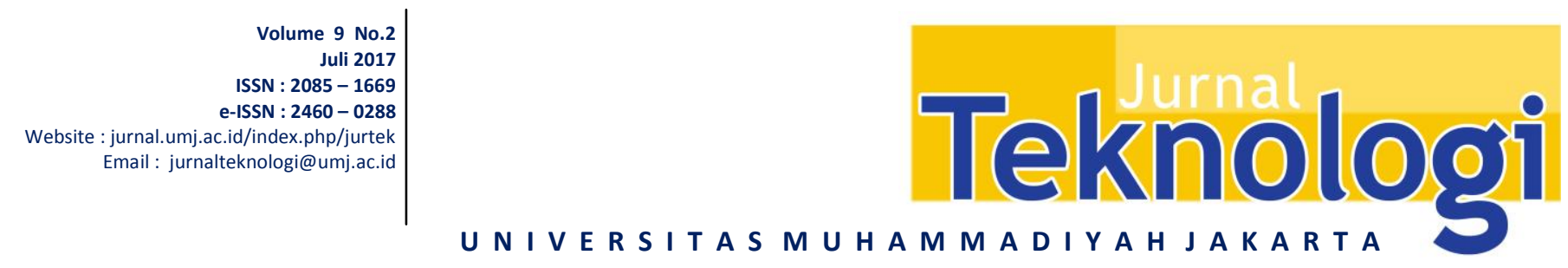

\title{
ANALISA DAN OPTIMASI SISTEM PLTGU BIOMASSA GAS METAN DENGAN DAYA 20 MW
}

\author{
Istianto Budhi Rahardja ${ }^{1}$, Wibowo Paryatmo ${ }^{2}$ \\ ${ }^{1}$ Teknologi Pengolahan Hasil Perkebunan, Politeknik Kelapa Sawit Citra Widya Edukasi, Bekasi, 17520 \\ ${ }^{2}$ Konversi Energi, Fakultas Teknik, Universitas Pancasila, Jl. Borobudur No. 7, Jakarta Pusat, 10320 \\ *E-mail : istianto@cwe.ac.id
}

\begin{abstract}
ABSTRAK
Pembangkit Listrik Tenaga Biomassa adalah pembangkit yang mempergunakan biomassa (sampah) dalam membentuk energi termal yang akan dipergunakan untuk menggerakan energi potensial pada sistem pembangkit listrik. Pada proses pembangkit ini mempergunakan sistem kombinasi (Combined Cycle), yaitu Pembangkit Listrik Tenaga Uap (siklus Rankine) dan Pembangkit Listrik Tenaga Gas (siklus Brayton). Proses Pembangkit Listrik Tenaga Gas - Uap (PLTGU) membutuhkan energi panas yang diproses dari sampah organik sehingga menjadi gas metan untuk dipergunakan menaikkan temperatur udara di dalam ruang bakar, sehingga mempunyai tekanan yang tinggi untuk mendorong/menggerakkan turbin gas dan bekas hasil kinerja turbin gas dimanfaatkan untuk pembakaran air menjadi uap di ruang ketel uap (Heat Recovery Steam Gas), sehingga mempunyai tekanan yang mampu untuk mendorong turbin uap. Penggabungan antara turbin gas dan turbin uap adalah pengembangan di dalam proses pembangkit listrik, dimana dengan melakukan penggabungan siklus (Combine Cycle) memperoleh effesiensi yang lebih tinggi sebesar (58.19\%) dengan dibandingkan dengan siklus turbin uap $(25.88 \%)$ serta siklus turbin gas $(30.1887 \%)$ yang berdiri sendiri.
\end{abstract}

Kata kunci : PLTGU, Biomassa, Gas Metan, Effesiensi,

\begin{abstract}
Power plant biomass is the power plant that uses biomass (waste) in forming thermal energy which will be used to run potential energy on power plant system. On the process this power plant used system combination (combined cycle), that is steam power plant (Rankine Cycle) and gas power plant (Brayton Cycle).The process of steam-gas power plant (PLTGU) requiring heat energy are processed of organic waste so as to become methane gas to be used raise the temperature of the air in the combuation room, so have the high pressure to push/move a gas turbine and former the results of the performance of a gas turbine be used for the combustion of water into steam in a steam boiler room (Heat Recovery of a Steam Gas), so have the pressure that capable to drive a steam turbine.The merger between a gas turbine and steam turbine is development in the process of power plant, which with perform the merger cycle (combined cycle) obtaining efficiency higher by (58.19\%) with compared with a steam turbine cycle $(25.88 \%)$ as well as gas turbine cycle $(30.1887 \%)$ that stands alone.
\end{abstract}

Password : PLTGU, Biomass, Methane Gas, Efficiency 


\section{PENDAHULUAN}

Perkembangan teknologi dan industri yang pesat pada saat ini membangkitkan roda perekonomian, perindustrian, maupun pemerintahan semakin pesat. Dengan pesat perkembangan diseluruh industri, maka akan menjadikan daerah tersebut semakin berkembang dan maju. Dengan perkembangan tersebut, maka diperlukan banyak sekali yang mendukung, yaitu : lingkungan, teknologi, sumber daya alam, dan manusia. Disamping dari perkembangan tersebut, akan menghasilkan produk dan hasil sampingannya adalah biomassa (sampah). Produk hasil jadi akan menghasilkan profil yang cukup tinggi nilainya dibandingkan dengan hasil produk sampingan. Produk sampingan sering kita sebut produk sisa (biomassa/sampah).

Pemerintah Republik Indonesia dalam Kebijakan Energi Nasional yang tertuang (Peraturan Presiden Republik Indonesia No. 5 tahun 2006), untuk mencapai elastisitas energi sampai dengan tahun 2025, maka penggunaan energi minyak bumi sebesar $20 \%$, gas bumi $30 \%$, batubara $33 \%$, bahan bakar nabati $5 \%$, panas bumi $5 \%$, energi baru dan terbarukan (biomassa, nuklir, tenaga air, tenaga surya dan tenaga angin) 5\%, dan batu bara yang dicairkan 2\%. Dengan dasar kebijakan ini, maka biomassa dapat dipergunakan sebagai energi pembangkit. Diperkuat (Keppres No. 1 tahun 2014) tentang Pedoman penyusunan Rencana Umum Energi Nasional (RUEN) dan Rencana Umum Energi Daerah (RUED). Berdasarkan (Undang-undang Nomor 18 Tahun 2008 tentang Pengelolaan Sampah), disebutkan bahwa sampah adalah sisa kegiatan sehari-hari manusia dan/atau proses alam yang berbentuk padat. Sampah dapat berada pada fase materi padat, cair, maupun gas. Apabila sampah berada pada fase cair dan gas, maka sampah disebut sebagai emisi. Fase cair akan membentuk lendir dan fase gas akan membentuk polusi lingkungan.

Biomassa (sampah) merupakan hasil proses yang dilakukan oleh mahluk hidup yang berupa padatan, cairan, dan gas. Hasil proses yang dilakukan oleh mahluk hidup adalah dalam kegiatan, sandang (pakaian), papan (tempat tinggal), maupun pangan (makanan). Bentuk yang terjadi pada biomassa, yaitu : aerobik (biomassa dapat terurai), anaerobik (biomassa yang tidak dapat terurai), serta bahan berbahaya dan beracun (B3). Dalam kehidupan sehari-hari setiap hari mahluk hidup sangat membutuhkan proses pembuangan sampah, dan hasil proses tersebut ada yang berupa padat (sandang, papan, pangan), berupa cair (pangan), dan berupa gas (hasil pangan) (Ade Basyarat, 2006).

Pada saat ini sampah merupakan barang/benda yang tidak mempunyai nilai profit, terhadap kehidupan. Dari program pemerintah yang sangat digalakkan untuk menanggulangi sampah terpadu, yaitu reused (penggunaan kembali), reduce (mengurangi), dan recycle (mengolah kembali)(Safrizal, 2014). Program ini digalakkan oleh pemerintah disebabkan banyak sekali sampah-sampah yang terdapat dilingkungan industri, pemerintahan, maupun masyarakat yang tidak dapat ditampung oleh Tempat Pengolahan Sampah (TPS) Kota. Dimana TPS yang terdapat di daerah perkotaan tidak dapat menampung sampah yang berada di daerahnya dan mengirimkan ke TPS daerah yang lain. Dengan tidak terolahnya sampah di daerah setempat menjadikan beberapa faktor kerugian, yaitu : pencemaran lingkungan yang menimbulkan pemandangan yang tidak enak dilihat oleh mata maupun bau yang menyengat, pemampatan saluran air yang menimbulkan penghambat saluran air dan menimbulkan banjir (Ade Basyarat, 2016). Dari kejadian tersebut perlu pemikiran khusus untuk mengolah sampah menjadi barang yang berguna dan mempunyai nilai baik bagi masyarakat. Sampah yang dianggap tidak mempunyai nilai yang positif, ternyata dibalik itu dapat memberikan kontribusi yang cukup baik dengan mengolah sampah dari segi ekonomis, maupun segi sosial. Terdapat pengolahan sampah yang dapat memberikan nilai dari segi ekonomis, yaitu : sampah memberikan nilai ekonomi bagi masyarakat yang melakukan recycle pada benda-benda yang masih dapat diolah, seperti kertas, plastik, karet, besi, maupun kaca. Benda-benda ini dapat memberikan nilai ekonomi dan dapat menghidupi ekonomi di sekitar TPS. Dari segi sosial, sampah yang telah dibuang oleh masyakat pada tempat sampah merupakan barang-barang yang sudah tidak berguna kembali, dengan menggunakan program reused, maka barang tersebut dapat dimanfaatkan kembali menjadi barang yang diolah menjadi barang-barang kerajinan, seperti : tas, tempat keranjang, dan lain-lain. 
Pada proses yang lain, seperti program reused (penggunaan kembali), sampah dapat diolah menjadi energi listrik, dimana energi ini merupakan energi baru dan terbarukan, dengan tidak menggunakan bahan bakar fosil (minyak bumi), sehingga pembiayaan dalam penyediaannya tidak lebih besar daripada pembangkit listrik menggunakan bahan bakar fosil (Kukuh, 2009).

Sampah yang telah ditimbun pada Tempat Pengolahan Sampah akan mengalami proses selanjutan untuk dibentuk menjadi energi. (Menurut Nandi, 2005), teknologi yang digunakan untuk proses lanjutan di TPS antara lain teknologi pembakaran, teknologi composting, teknologi daur ulang. Pada proses pembakaran terdapat pengaruh maupun akibat yang ditimbulkan pada lingkungan sekitar, dimana pembakaran menghasilkan pengotor (debu, asap, karbondioksida, karbon monoksida, dan lain-lain) yang dapat mencemari lingkungan. Pada kondisi seperti ini perlu diperhatikan dan dipikirkan untuk menanggulangi akibat yang terjadi pada proses pembakaran sampah, sehingga lingkungan sekitar tidak rusak dan tercemar. Teknologi kompos sampah organik adalah dengan cara menimbun sampah sehingga terurai dan dapat dipergunakan sebagai penyuburan tanaman. Adapun daur ulang yang dipergunakan pada sampah solid yang tidak dapat terurai, maka dipergunakan teknologi daur ulang untuk memproses kembali menjadi bahan/benda yang memiliki nilai jual. Pada dasarnya, yang dimaksud dengan teknologi pembakaran sampah adalah mengkonversi sampah menjadi energi dengan menggunakan proses termal. Energi yang dihasilkan tersebut dapat dimanfaatkan sebagai pembangkit listrik. Oleh karena itu, teknologi pembakaran sampah yang menghasilkan listrik dikenal sebagai Pembangkit Listrik Tenaga Biomassa (PLTBiomassa)(Ahmad Agus dkk, 2010). (Menurut Hutagalong, 2007), proses konversi termal pada proses pembakaran sampah dapat dilakukan dengan beberapa cara, yaitu dengan cara : insinerasi, pirolisis, dan gasifikasi. Adapun gambar skema proses konversi termal Biomassa dapat dilaihat pada gambar1.

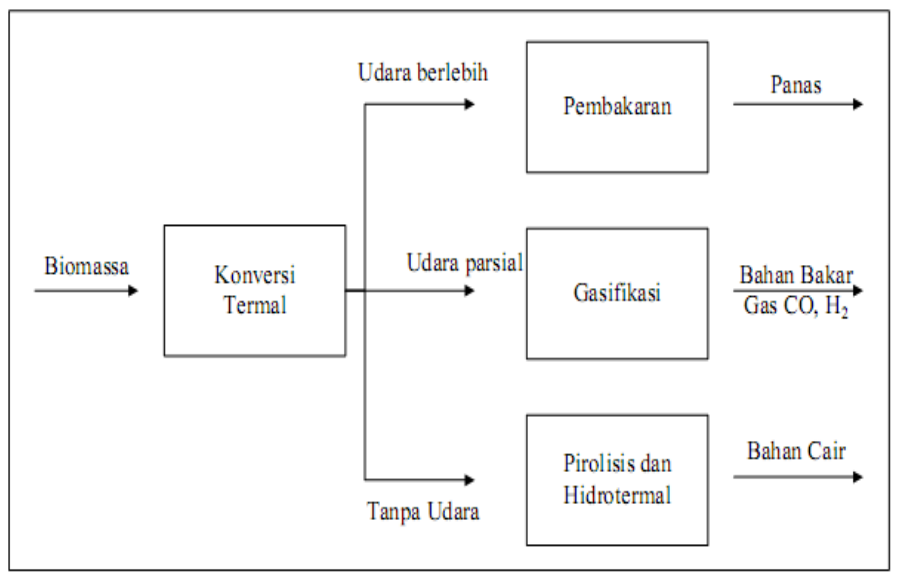

Gambar 1. Skema Proses Konversi Termal Biomassa

Permasalahan sampah di daerah ibukota dan daerah yang menyokong terhadap perkembangan ibukota semakin banyak dan semakin meningkat. Dimana kita ketahui bersama bahwa, di daerah kota-kota besar dan sekitarnya tumbuh dan berkembang kehidupan perekonomian. Disamping pertumbungan perekonomian yang perlu diperhatian adalah dengan perkembangan jumlah penduduk, maka akan menimbulkan permasalahan yang lebih meningkat. Dimana sampah yang akan menjadi hasil proses kehidupan akan semakin banyak dan semakin meningkat. Dari sampah yang terdapat di perkotaan, tidak seluruhnya dapat dilakukan proses reused, reduce, recycle. Maka dengan demikian perlu diketahui terlebih dahulu bahan-bahan yang dapat dipergunakan (Murni, 2012).

(Habiba dkk, 2006) Pada pembangkit listrik yang mempunyai bahan bakar cair maupun gas dapat mempergunakan siklus Brayton, dimana udara dari luar sistem dimasukan dan dikompresikan ke dalam suatu ruangan, sehingga mempunyai tekanan yang 
tinggi dan dilakukannya pembakaran gas hasil pengolahan sampah yang berupa metan. Dengan pembakaran tersebut, maka diperoleh gas pembakaran dengan temperatur dan tekanan yang tinggi. Hasil pembakaran gas tersebut dapat dipergunakan untuk memutar turbin gas dalam siklus Brayton. Pada pengolahan sampah padat yang menjadi pembangkit listrik, yaitu berupa zat atau benda yang mudah terbakar dan kering, dimana sampah yang terdapat di dalam TPS harus melalui proses pengeringan maupun pemanasan, sehingga dapat mudah terbakar pada saat diberikan titik api. Api yang telah ada akan memanaskan ketel uap sebagai pembentuk uap, sehingga uap tersebut dapat dipergunakan dalam memutar turbin uap. Dari perputaran turbin uap, maka akan menggerakkan generator sebagai alat pembangkit listrik yang akan dikonsumsi oleh daerah tersebut menjadi energi listrik. Uap yang telah dipakai untuk menggerakkan turbin, akan di kondensasi menggunakan heat exchanger sehingga air tersebut dapat dikembalikan/dipergunakan kembali oleh pompa sebagai alat pemindah zat cair. Proses tersebut akan dikembalikan kembali ke ketel uap, dan begitu seterusnya proses tersebut beroperasi. Operasi proses pembangkit tenaga

\section{SIKLUS GABUNGAN (COMBINED CYCLE)}

Siklus gabungan (combined cycle) merupakan penggabungan antara sistem yang berbeda dengan tujuan untuk menghasilkan kinerja sebuah unit yang lebih baik dan meningkatkan effesiensi. Dengan menggabungkan sistem yang ada diharapkan dapat meningkatkan daya kerja dan menghasilkan kapasitas yang memenuhi target listrik yang dipergunakan adalah siklus Rankine. Pada pengembangan di dalam pembangkit listrik, ternyata tidak hanya mempergunakan siklus Brayton maupun siklus Rankine, namun dapat digabungkan sistem tersebut di dalam pembangkit listrik. Sistem tersebut sering disebut Siklus Kombinasi (Combined Cycle)(Dyos \& Hasan, 2011).

Dengan melihat permasalahan yang dihadapi untuk mengoperasikan sistem pembangkit listrik tersebut, maka diperlukan analisa dan optimasi dari sistem pembangkit listrik yang dapat dipergunakan dengan proses hasil pemanasan dari hasil pembakaran gas. Untuk mendapatkan sistem yang tepat sebelum dilakukan pembangunan, percobaan, dan pengoperasian, maka dapat dilakukan analisa baik dan benar, sehingga akan memperoleh hasil yang maksimal pada saat dilakukannya aktualisasi dari perencanaan. Dengan melakukan analisa secara sebaik mungkin diharapkan akan menghasilkan sistem Pembangkit Listrik dengan performa yang baik dan optimal di dalam operasionalnya. Dari permasalahan tersebut di atas, akan dikaji yaitu "Analisa Dan Optimasi Sistem PLGU Biomassa Gas Metan Dengan Daya 20 MW".

yang diinginkan. Dalam proses pengembangan pembangkit listrik dapat dilakukan penggabungan dari sistem yang berbahan bakar padat dan gas, dimana sistem pembangkit listrik tersebut adalah Pembangkit Listrik Tenaga Gas-Uap (PLTGU). (M.M. ElWakil, 1988) adapun skematik dari PLTGU dapat dilihat pada gambar 2 .

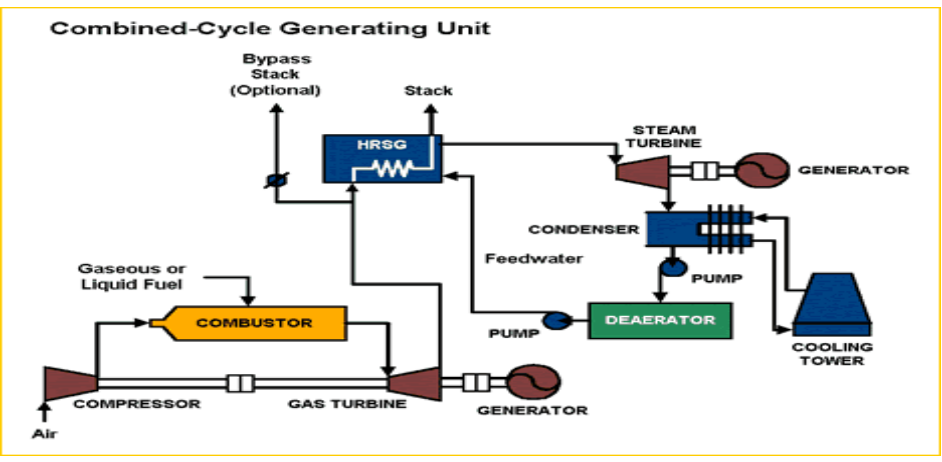

Gambar 2. Skematik Pembangkit Listrik Tenaga Gas-Uap

Yunus A. Cengel, 2007 menggambarkan diagram T-s siklus kombinasi pada Gambar 3. 

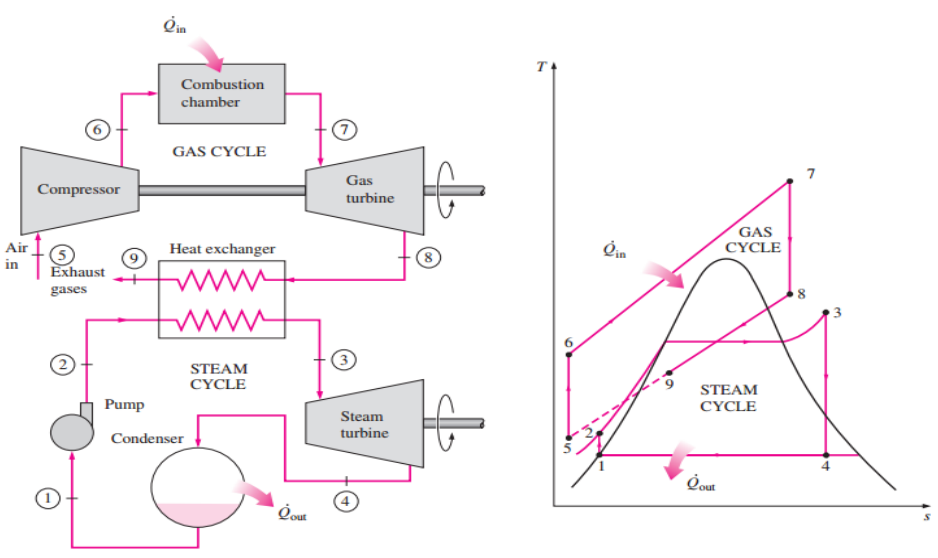

Gambar 3. Diagram T-s siklus PLTGU

Diagram T-s yang menggambarkan keseluruhan proses ditunjukkan pada Gambar di atas. Diagram Gas Cycle menyatakan siklus Brayton untuk turbin gas dan diagram Steam Cycle menyatakan siklus Rankine untuk turbin uap. Kapasitas produksi uap yang dapat dihasilkan tergantung pada kapasitas energi panas yang masih terkandung di dalam gas buang yang berasal dari turbin gas. Hal ini berarti produksi uap tergantung pada beban unit turbin gas. (Yunus A. Cengel, 2007) Penggabungan di dalam sistem pembangkit ini (Siklus Rankine-Brayton) adalah ingin menghasilkan pemanasan di dalam ketel uap yang lebih baik, dimana gas hasil kerja dari turbin gas dapat dipergunakan kembali untuk memanaskan ketel uap, sehingga kinerja menjadi efektif. Dengan menaikkan temperatur di dalam ketel uap (dengan bantuan pemanasan dari turbin gas), maka uap hasil pembakaran di dalam ketel uap menjadi meningkat. Dengan meningkatnya uap yang dihasilkan oleh ketel uap, maka kapasitas uap yang terbentuk semakin besar dan dapat memutarkan turbin uap yang lebih besar kapasitasnya dibandingkan dengan menggunakan siklus PLTU. Pada proses sistem Pembangkit Listrik Tenaga Gas Uap mengoperasikan turbin gas yang masih mempunyai temperatur tinggi setelah memutarkan turbin gas. Sisa hasil pembakaran yang telah melakukan kerja turbin, kemudian temperatur tersebut dipergunakan untuk memanaskan air yang berada di dalam ketel uap. Fasa air yang berada di dalam ketel semakin lama temperaturnya semakin tinggi, dan mencapai titik didih air, serta menjadi fasa uap.
(Dyos \& Hasan, 2007) Siklus kombinasi pembangkit gas-uap yang ada di Unit PLTGU memperlihatkan komponen memberikan kontribusi terbesar terhadap pemusnahan eksergi adalah ruang bakar. Persentase rasio pemusnahan eksergi pada masing-masing komponen terhadap pemusnahan eksergi total maksimum diperoleh pada ruang bakar $(59.76 \%)$, dikuti oleh HRSG (13.19\%), turbin gas $(9.74 \%)$, kompresor $(7.39 \%)$, turbin uap $(7.06 \%)$, kondensor $(2.71 \%)$ dan kemudian pompa $(0.15 \%)$. Eksergi yang dibawa oleh gas buang ke atmosfir (4.0\% dari eksergi total bahan bakar). Menurut Kukuh (2009), Pembangunan pembangkit listrik tenaga sampah (PLTSa) merupakan solusi kebutuhan energi baru terbarukan (EBT) untuk meningkatkan kebutuhan energi serta membantu mengurangi ketergantungan terhadap energi fosil. (Yohana dkk et al., 2012) Heat Recovery Steam Generator (HRSG) adalah suatu komponen kesatuan antara turbin gas dan turbin uap pada sistem combine cycle power plant. HRSG berfungsi sebagai alat yang memanfaatkan gas buang dari turbin gas untuk memanaskan air pada pipa-pipa yang berada di dalam HRSG hingga menjadi uap kering yang mampu memutar turbin uap. (Habiba dkk, et al.,2006) Instalasi kombinasi (combined cycle) adalah sebuah proses tenaga uap dibagian depannya dihubungkan dengan instalasi turbin gas, sehingga terbentuk instalasi kombinasi turbin gas dan uap, dimana gas bekas yang keluar dari turbin gas masih memiliki elthalpy dan temperatur yang cukup tinggi dimanfaatkan sebagai udara pembakaran pada ketel uap untuk mengubah air menjadi uap serta 
menggerakkan turbin uap. Instalasi sistem gabungan mampu meningkatkan efesiensi Dalam mengekspresikan siklus gabungan, maka dapat dituliskan persamaan siklus Rankine dan siklus Brayton. Pada siklus Rankine untuk mengetahui kerja setiap

- Proses Pompa

$$
W_{\text {pompa }}=h_{2}-h_{1}
$$

- Proses Boiler

$$
q_{\text {in }}=q_{2-3}=h_{3}-h_{2}
$$

- Proses Turbin Uap

$$
W_{\text {turbin }}=h_{3}-h_{4}
$$

- Proses Kondensor

$$
q \text { out }=h_{4}-h_{1}
$$

Effesiensi termal siklus Rankine dapat diekspresikan dalam persamaan sebagai berikut (Yunus A. Cengel, 2007):

$$
\eta_{\text {th rankine }}=\frac{w \text { net }}{q \text { in }}=1-\frac{q \text { out }}{q \text { in }}
$$

dimana untuk mengetahui kerja bersih dari siklus Rankine dapat diekspresikan dengan persamaan sebagai berikut (Yunus A. Cengel, 2007):

$$
w_{\text {net }}=q_{\text {in }}-q_{\text {out }}=w_{\text {turbin }}-w_{\text {pompa }}(6)
$$

Dengan demikian dapat dihitung kerja netto siklus, yaitu (Yunus A. Cengel, 2007):

Berdasarkan Diagram T-s dan P-v di atas, maka dapat dicari nilai efisiensi thermal siklus $\left(\eta_{\mathrm{th}}\right)$. Efisiensi thermal didefinisikan sebagai rasio antara kerja netto siklus terhadap kalor

$$
\begin{aligned}
& \eta_{\mathrm{th}}=\frac{W_{\text {net }}}{q \text { in }}=1-\frac{q \text { out }}{q \text { in }} \\
& \text { atau } \\
& \eta_{\text {th }}=1-\frac{C p(T 4-T 1)}{C p(T 3-T 2)}=1-\frac{T 1\left(\frac{T 4}{T / 1}-1\right)}{T 2\left(\frac{T_{\mathrm{s}}}{T 2}-1\right)}
\end{aligned}
$$

termis sampai sekitar $42 \%$.

peralatan di dalam sistem dapat diekspresikan dengan persamaan sebagai berikut (Yunus A. Cengel, 2007):

Dari siklus Brayton dapat diperoleh persamaan pada setiap proses yaitu (Yunus A. Cengel, 2007):

roses $1-2$ (kompresi isentropis di kompresor)

$w_{\text {comp }}=h_{2}-h_{1}=C_{P}\left(T_{2}-T_{1}\right)$

roses $2-3$ (pemanasan pada $\mathrm{P}$ konstan)

$q_{\text {in }}=h_{3}-h_{2}=C_{P}\left(T_{3}-T_{2}\right)$

roses $3-4$ (ekspansi isentropis di turbin)

$w_{\text {turb }}=h_{3}-h_{4}=C_{P}\left(T_{3}-T_{4}\right)$

roses $4-1$ (pelepasan kalor pada $\mathrm{P}$ konstan)

$$
\begin{aligned}
& q_{\text {out }}=h_{4}-h_{1}=C_{P}\left(T_{4}-T_{1}\right) \\
& w_{\text {netto }}=w_{\text {turb }}-w_{\text {comp }}
\end{aligned}
$$

yang diberikan (kalor input). Dalam persamaan dapat ditulis sebagai berikut (Yunus A. Cengel, 2007): 
METODE PENELITIAN

Pada kerangka penelitian, penulis melakukan langkah pada gambar 9.

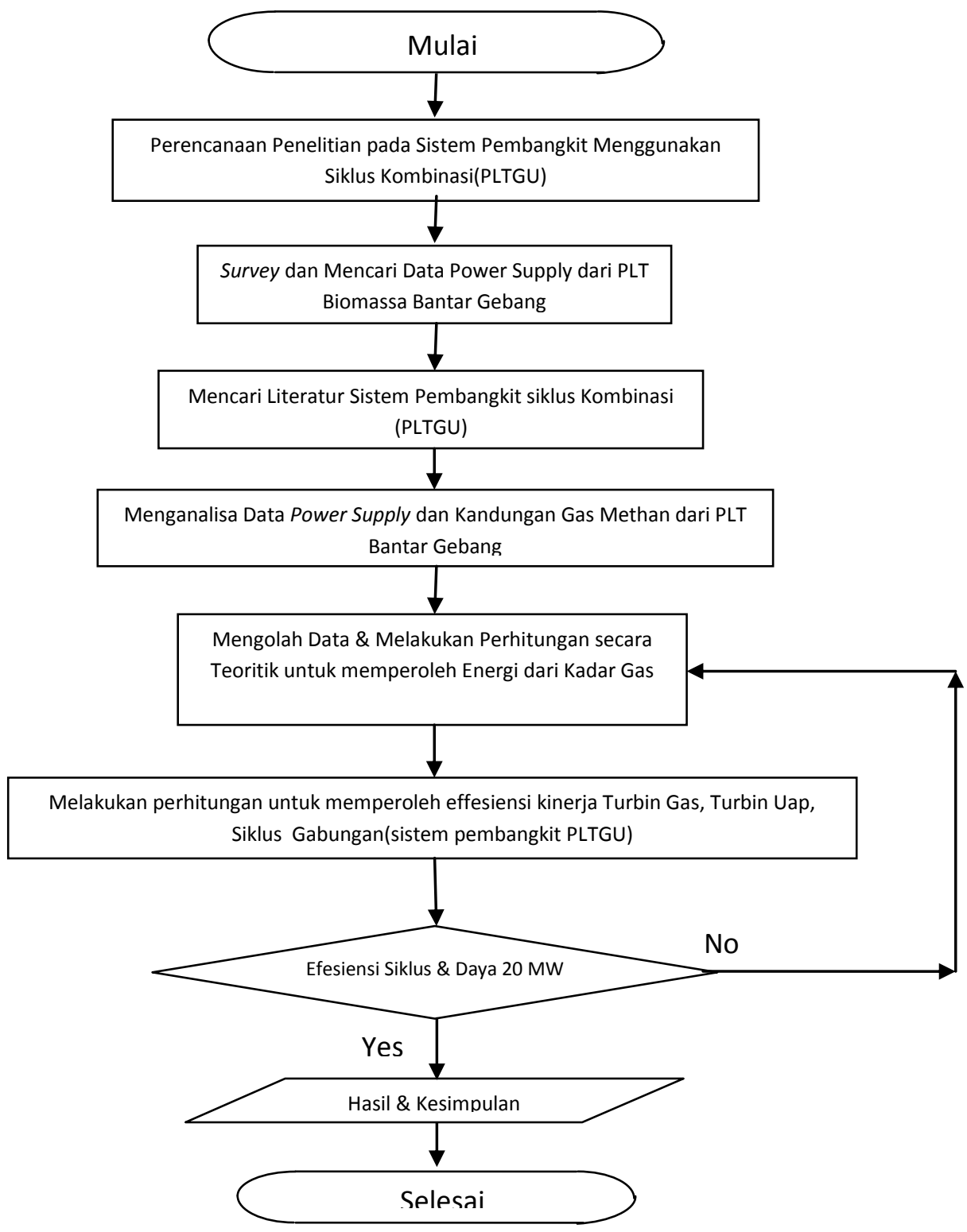

Gambar 9. Flow Chart Kerangka Penelitian 


\section{HASIL DAN PEMBAHASAN}

\section{Perhitungan Turbin Uap \& Gas}

Pada siklus Rankine untuk kerja diekspresikan dengan persamaan berikut:

- Proses Pompa

$$
W_{\text {pompa }}=h_{2}-h_{1}
$$

Untuk memperoleh kerja pompa yang terjadi pada proses ini, yaitu perlu mengetahui tekanan air yang akan dioperasikan di dalam sistem, dimana dengan mengetahui $T 1=30^{\circ} \mathrm{C}$ $W_{\text {pompa }}=v(\Delta P)=v(P 2-P 1)$

$W_{\text {pompa }}=0.001017 \mathrm{~m}^{3} / \mathrm{kg} \times(19.947 \mathrm{kPa}-$ $4.2469 \mathrm{kPa})$

- Proses Ketel Uap

$q_{\text {in }}=q_{2-3}=h_{3}-h_{2}$

$q_{\text {in }}=3280 \mathrm{~kJ} / \mathrm{kg}-251 \mathrm{~kJ} / \mathrm{kg}$

- Proses Turbin Uap

$W_{\text {turbin }}=h_{3}-h_{4}$

$W_{\text {turbin }}=3280 \mathrm{~kJ} / \mathrm{kg}-2370 \mathrm{~kJ} / \mathrm{kg}$

- Proses Kondensor

$q$ out $=h_{4}-h_{1}$

Efesiensi siklus Rankine adalah sebagai berikut:

$\eta$ th rankine $=\frac{w \text { net }}{q \text { in }}=1-\frac{q \text { out }}{q \text { in }}$

Kerja bersih turbin uap adalah sebagai berikut :

$W_{\text {net turbin uap }}=W$ turbin $-W$ pompa

Turbin gas dalam sistem operasionalnya memiliki unit kompresi, pembakaran bahan

- Kerja kompresor

$W_{\text {kompresor }}=C p .(T 2-T 1)$

$W_{\text {kompresor }}=2.2537 \mathrm{~kJ} / \mathrm{kgK} \times\left(100^{\circ} \mathrm{C}-30^{\circ} \mathrm{C}\right)$

- Proses pembakaran

$q_{\text {in }}=C p .(T 3-T 2)$

$q_{\text {in }}=2.2537 \mathrm{~kJ} / \mathrm{kgK} \times\left(630^{\circ} \mathrm{C}-100^{\circ} \mathrm{C}\right)$

- Kinerja turbin gas

$W_{\text {turbin }}=C p$. $(T 3-T 4)$

$W_{\text {turbin }}=2.2537 \mathrm{~kJ} / \mathrm{kgK} \times\left(630^{\circ} \mathrm{C}-400^{\circ} \mathrm{C}\right)$

- Tekanan pada turbin gas adalah:

$\frac{T 3}{T 4}=\left[\frac{P 3}{P 4}\right]^{(k-1) / k}$

$\frac{630^{\circ} \mathrm{C}}{400^{\circ} \mathrm{C}}=\left[\frac{P 2}{1 \mathrm{~atm}}\right]^{(1.299-1) / 1.299}$

- Langkah buang

$q_{\text {out }}=C p .(T 4-T 1)$

Hasil kerja per satuan massa dari turbin gas dapat diekspresikan melalui persamaan sebagai berikut :

Efesiensi kerja yang diperoleh di dalam sistem dapat diekspresikan melalui persamaam sebagai berikut:

$\eta_{\text {th }}=\frac{W_{\text {net }}}{q \text { in }}=1-\frac{q \text { out }}{q \text { in }}$

$$
\begin{aligned}
& W_{\text {pompa }}=251 \mathrm{~kJ} / \mathrm{kg}-125 \mathrm{~kJ} / \mathrm{kg} \\
& W_{\text {pompa }}=126 \mathrm{~kJ} / \mathrm{kg}
\end{aligned}
$$

dan $T 2=60^{\circ} \mathrm{C}$, maka diperoleh tekanan pada tabel air $P 1=4.2469 \mathrm{kPa}, P 2=19.947 \mathrm{kPa}$. Dengan demikian dapat diperoleh kerja pompa yaitu :

$$
\begin{aligned}
& W_{\text {pompa }}=0.001017 \mathrm{~m}^{3} / \mathrm{kg} \times 15.7001 \mathrm{kPa} \\
& W_{\text {pompa }}=0.015967 \mathrm{~kJ} / \mathrm{kg}=15.967 \mathrm{~J} / \mathrm{kg} \\
& q_{\text {in }}=3029 \mathrm{~kJ} / \mathrm{kg} \\
& W_{\text {turbin }}=910 \mathrm{~kJ} / \mathrm{kg} \\
& q_{\text {out }}=2370 \mathrm{~kJ} / \mathrm{kg}-125 \mathrm{~kJ} / \mathrm{kg} \\
& q_{\text {out }}=2245 \mathrm{~kJ} / \mathrm{kg} \\
& \eta_{\text {th rankine }}=1-\frac{(2245 \mathrm{~kJ} / \mathrm{kg})}{(3029 \mathrm{~kJ} / \mathrm{kg})} \\
& \eta_{\text {th rankine }}=0.258831=25.8831 \% \\
& W_{\text {net turbin uap }}=910 \mathrm{~kJ} / \mathrm{kg}-126 \mathrm{~kJ} / \mathrm{kg} \\
& W_{\text {net turbin uap }}=784 \mathrm{~kJ} / \mathrm{kg}
\end{aligned}
$$

bakar, serta kerja turbin, serta pembuangan gas, dimana kinerjanya dapat diperoleh yaitu :

$W_{\text {kompresor }}=157.759 \mathrm{~kJ} / \mathrm{kg}$

$q_{\text {in }}=1194.461 \mathrm{~kJ} / \mathrm{kg}$

$W_{\text {turbin }}=518.351 \mathrm{~kJ} / \mathrm{kg}$

Dimana $: k=1.299 ; C p=2.2537 \mathrm{~kJ} / \mathrm{kg} . \mathrm{K}$; $C v=1.7354 \mathrm{~kJ} / \mathrm{kg} . \mathrm{K} ; k=C p / C v ; P 3=$ $7.208023 \mathrm{~atm}$, dengan $P 4=1 \mathrm{~atm}$

$$
\begin{aligned}
& q_{\text {out }}=2.2537 \mathrm{~kJ} / \mathrm{kgK} \times\left(400^{\circ} \mathrm{C}-30^{\circ} \mathrm{C}\right) \\
& q_{\text {out }}=833.869 \mathrm{~kJ} / \mathrm{kg} \\
& W_{\text {net }}=W_{\text {turbin }}-W_{\text {kompresor }} \\
& W_{\text {net }}=518.351 \mathrm{~kJ} / \mathrm{kg}-157.759 \mathrm{~kJ} / \mathrm{kg} \\
& W_{\text {net }}=360.592 \mathrm{~kJ} / \mathrm{kg} \\
& \eta_{\text {th }}=\frac{(360.592 \mathrm{~kJ} / \mathrm{kg})}{(1194.461 \mathrm{~kJ} / \mathrm{kg})} \\
& \eta_{\text {th }}=0.301886792 \\
& \eta_{\text {th }}=30.1887 \%
\end{aligned}
$$


Hubungan antara effesiensi yang terjadi pada siklus Brayton dengan perbedaan tekanan gas $\eta_{\mathrm{th}}=1-\frac{1}{r p^{(k-1) / k}}$

$30.1887 \%=1-\frac{1}{r p(1,2 n 998-1) f_{1.22998}}$

Dengan memperoleh harga perbedaan tekanan (pressure ratio) sebesar 4.77, maka dapat $r p=\frac{P_{2}}{P_{1}}$

$4.77=\frac{P_{2}}{1 \mathrm{~atm}}$

\section{Siklus Kombinasi PLTGU}

Dengan mengetahui data-data perencanaan pada turbin gas dan turbin uap yang akan dilakukan penggabungan siklus, maka dapat diperoleh hasil perhitungan untuk Tabel 1. Data Perhitungan Turbin Gas

\begin{tabular}{|l|l|l|}
\hline No & Item & Nilai \\
\hline 1 & $\mathrm{~T} 1\left({ }^{\circ} \mathrm{C}\right)$ & 30 \\
\hline 2 & $\mathrm{~T} 2\left({ }^{\circ} \mathrm{C}\right)$ & 100 \\
\hline 3 & $\mathrm{~T} 3\left({ }^{\circ} \mathrm{C}\right)$ & 630 \\
\hline 4 & $\mathrm{~T} 4\left({ }^{\circ} \mathrm{C}\right)$ & 400 \\
\hline 5 & $\mathrm{~h} 1(\mathrm{~kJ} / \mathrm{kg})$ & 67.611 \\
\hline 6 & $\mathrm{~h} 2(\mathrm{~kJ} / \mathrm{kg})$ & 225.37 \\
\hline 7 & $\mathrm{~h} 3(\mathrm{~kJ} / \mathrm{kg})$ & 1419.831 \\
\hline 8 & $\mathrm{~h} 4(\mathrm{~kJ} / \mathrm{kg})$ & 901.48 \\
\hline 9 & $W_{\text {kompresor }}(\mathrm{kJ} / \mathrm{kg})$ & 157.759 \\
\hline 10 & $q_{\text {in }}(\mathrm{kJ} / \mathrm{kg})$ & 1194.461 \\
\hline 11 & $W_{\text {turbin }}(\mathrm{kJ} / \mathrm{kg})$ & 518.351 \\
\hline 12 & $q_{\text {out }}(\mathrm{kJ} / \mathrm{kg})$ & 833.869 \\
\hline 13 & $W_{\text {net }}(\mathrm{kJ} / \mathrm{kg})$ & 360.592 \\
\hline 14 & $\eta$ th $(\%)$ & 30.1887 \\
\hline
\end{tabular}

Sumber : data olahan 2015

Dengan memperoleh data-data perhitungan pada siklus turbin gas dan turbin uap, pada tebel 1 \& 2 terlihat perbedaan temperatur untuk siklus Turbin gas pada T2 (temperatur pengkompresian) sebesar $100^{\circ} \mathrm{C}$, T3(temperaur pembakaran) sebesar $630^{\circ} \mathrm{C}$, serta hasil pembakaran (T4) sebesar $400^{\circ} \mathrm{C}$. Sedangkan pada Turbin uap, T2 hanya sebesar $60^{\circ} \mathrm{C}$, T3 (hasil pembakaran/temperatur sisa pembakaran turbin gas diberikan kepada turbin air) sebesar $400^{\circ} \mathrm{C}$, dan $\mathrm{T} 4$ (temperatur kondensasi) sebesar $60^{\circ} \mathrm{C}$ ). Dari kedua tabel 1 \& 2 di atas menghasilkan kinerja tiap proses peralatan, dimana turbin uap dapat membangkitkan lebih besar dari turbin gas masuk dan keluar, dapat diekspresikan dengan persamaan, sebagai berikut:

$$
\begin{aligned}
& 0.301887=1-\frac{1}{r p^{(0.22998)}} \\
& r p=4.77
\end{aligned}
$$

diketahui tekanan yang ke luar dari unit kompresor adalah sebagai berikut :

$P 2=4.77 \mathrm{~atm}$

siklus kombinasi. Data perhitungan dari turbin gas dan uap dapat diperlihatkan pada tabel 1 dan 2 .

Tabel 2. Data Perhitungan Turbin Uap

\begin{tabular}{|l|l|l|}
\hline No & Item & Nilai \\
\hline 1 & $\mathrm{~T} 1\left({ }^{\circ} \mathrm{C}\right)$ & 30 \\
\hline 2 & $\mathrm{~T} 2\left({ }^{\circ} \mathrm{C}\right)$ & 60 \\
\hline 3 & $\mathrm{~T} 3\left({ }^{\circ} \mathrm{C}\right)$ & 400 \\
\hline 4 & $\mathrm{~T} 4\left({ }^{\circ} \mathrm{C}\right)$ & 60 \\
\hline 5 & $\mathrm{~h} 1(\mathrm{~kJ} / \mathrm{kg})$ & 125 \\
\hline 6 & $\mathrm{~h} 2(\mathrm{~kJ} / \mathrm{kg})$ & 251 \\
\hline 7 & $\mathrm{~h} 3(\mathrm{~kJ} / \mathrm{kg})$ & 3280 \\
\hline 8 & $\mathrm{~h} 4(\mathrm{~kJ} / \mathrm{kg})$ & 2370 \\
\hline 9 & $W_{\text {pompa }}(\mathrm{kJ} / \mathrm{kg})$ & 126 \\
\hline 10 & $q_{\text {in }}(\mathrm{kJ} / \mathrm{kg})$ & 3029 \\
\hline 11 & $W_{\text {turbin }}(\mathrm{kJ} / \mathrm{kg})$ & 910 \\
\hline 12 & $q_{\text {out }}(\mathrm{kJ} / \mathrm{kg})$ & 2245 \\
\hline 13 & $W_{\text {net }}(\mathrm{kJ} / \mathrm{kg})$ & 784 \\
\hline 14 & $\eta$ th $(\%)$ & 25.8831 \\
\hline
\end{tabular}

Sumber : data olahan 2015

(59.96\%). Kinerja yang lain juga diikuti oleh beberapa proses, yaitu seperti di temperatur pemanasan (T3), kerja turbin (T4), dan kerja bersih $\left(W_{\text {net }}\right)$ dari sistem. Untuk effesiensi turbin gas sebesar $30.18 \%$ dan Turbin uap sebesar $25.88 \%$. adapun siklus gambungan dari data tabel $1 \& 2$ dapat dilukiskan pada gambar 5. Pada gambar 5, menunjukkan setiap siklus operasi peralatan turbin gas dan turbin uap secara jelas. Siklus Turbin gas, pada pembuangan gas panas (T4-T1) saling bersentuhan dengan proses Turbin uap (T2T3). Disini terjadi penyerapan energi panas oleh turbin uap untuk memanaskan air di dalam ketel. 
Mengetahui perbandingan laju aliran massa yang dapat diperoleh dari persamaan $E$ in $=E$ out

$m g \cdot h 5+m s \cdot h 3=m g \cdot h 4+m s \cdot h 2$

$m s(h 3-h 2)=m g(h 4-h 5)$

Hal ini berarti $1 \mathrm{~kg}$ gas pembakaran hanya dapat memanaskan $0.1848266 \mathrm{~kg}$ uap dari temperatur $30^{\circ} \mathrm{C}$ menjadi $400^{\circ} \mathrm{C}$, sekaligus

$w_{\text {net }}=w_{\text {net.gas }}+y \cdot w_{\text {net.steam }}$

Sehingga setiap $1 \mathrm{~kg}$ gas hasil pembakaran maka PLTGU akan menghasilkan kerja $\eta \mathrm{R}=\frac{W \text { netsiklus gabungan }}{q \text { in siklus turbingas }} \times 100 \%$

$\eta \mathrm{R}=\frac{(325.814 \mathrm{~kJ} / \mathrm{kg})}{(559.84 \mathrm{~kJ} / \mathrm{kg})} \times 100 \%$

$\eta \mathrm{R}=0.5819$ keseimbangan energi pada pertukaran kalor (heat exchanger), yaitu :

$m s(3$ 280-251) $=m g(933.51-373.67)$

$m g / m s=(559.84) /(3029)$

$m g / m s=0.1848266$

mendinginkan gas dari temperatur $400^{\circ} \mathrm{C}$ menjadi $30^{\circ} \mathrm{C}$. Sehingga kerja netto total tiap 1 $\mathrm{kg}$ gas hasil pembakaran adalah :

$=180.91+(0.1848266 \times 784)$

$=325.814 \mathrm{~kJ} / \mathrm{kg}$

sebesar $325.814 \mathrm{~kJ} / \mathrm{kg}$. Untuk mengetahui efisiensi thermal siklus kombinasi ( $\eta \mathrm{R})$ adalah : $\eta \mathrm{R}=58.19 \%$

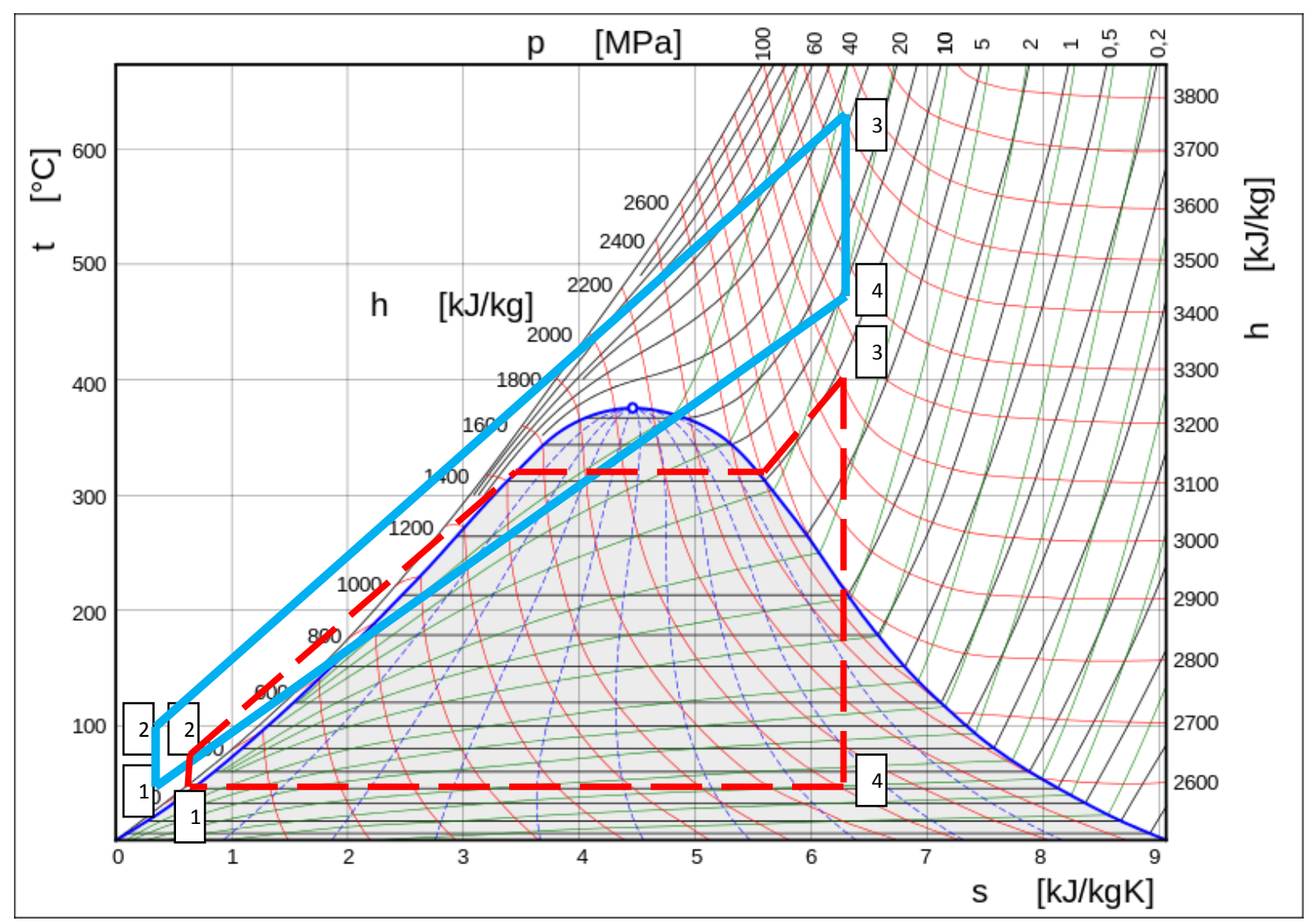

Gambar 5. Siklus Kombinasi (Turbin Gas - Uap) pada T-s Diagram

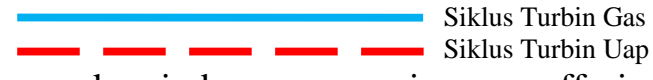

Siklus Turbin Gas
Siklus Turbin Uap

Berdasarkan perhitungan keseimbangan energi pada pertukaran kalor dari laju aliran massa di atas, secara sederhana perhitungan kerja dan effesiensi siklus kombinasi (Turbin gas dan Turbin Uap) dapat dilihat pada tabel 3. 
Tabel 3. Perhitungan Kerja dan Effesiensi Siklus Kombinasi

\begin{tabular}{|c|c|c|c|c|}
\hline $\begin{array}{c}\text { h uap } \\
(h 3-\mathrm{h} 2) \\
\mathrm{kJ} / \mathrm{kg}\end{array}$ & $\begin{array}{c}\text { h gas } \\
(\mathrm{h} 3-\mathrm{h} 2) \\
\mathrm{kJ} / \mathrm{kg}\end{array}$ & mg/ms= & $\begin{array}{c}\text { W net }=\text { Wnet } \text { gas }+ \\
\boldsymbol{Y} \text { Wnet } \text { steam }\end{array}$ & $\begin{array}{c}\text { efesiensi } \boldsymbol{\eta}= \\
\text { Wnet } / \text { Qin gas } \\
(\boldsymbol{\%})\end{array}$ \\
\hline $3029 \mathrm{~kJ} / \mathrm{kg}$ & $559.84 \mathrm{~kJ} / \mathrm{kg}$ & 0.184826675 & $325.8141136 \mathrm{~kJ} / \mathrm{kg}$ & $0.581977196 \%$ \\
\hline
\end{tabular}

Sumber : data olahan 2015

\section{Perhitungan Turbin Gas\&Uap Berbentuk kWatt}

Laju aliran yang terjadi adalah sebesar 1178 $\mathrm{m}^{3} / \mathrm{h}$, dengan kadar $\mathrm{CH}_{4}$ (gas methan) sebesar $43.1 \%$, maka gas metan yang tersedia adalah : $m=1178 \mathrm{~m}^{3} / \mathrm{h} \times 43.1 \%$, $m=506.5923 \mathrm{~m}^{3} / \mathrm{h}$ $m=\frac{506.5923 \mathrm{~m}^{2} / \mathrm{h}}{0.00615 \mathrm{~m}^{2} / \mathrm{kg}}$

Dengan mengetahui kinerja bersih yang terjadi pada turbin gas, maka dapat diperoleh kerja $W_{\text {net }}(\mathrm{kW})=m(\mathrm{~kg} / \mathrm{s}) \times W \operatorname{net}(\mathrm{kJ} / \mathrm{kg})$

$W_{\text {net turbin gas }}=W_{\text {turbin }}-W_{\text {kompresor }}$

Maka untuk kerja bersih dari turbin gas adalah sebagai berikut :

$W_{\text {net }}=22.881 \mathrm{~kg} / \mathrm{s} \times 360.592 \mathrm{~kJ} / \mathrm{kg}$

$W_{\text {net }}=8250.7055 \mathrm{~kW}$

Dengan mengetahui rancangan yang telah dibuat, yaitu 4 unit turbin gas dengan daya yang dimiliki setiap turbin gas adalah $2 \mathrm{MW}$, maka dapat diperoleh bahwa rancangan yang telah dibuat cukup memenuhi syarat daya yang dibutuhkan, yaitu 8.251 MW dibagi 4 unit sebesar 2.06275 MW (cukup untuk $W_{\text {net }}(\mathrm{kW})=m(\mathrm{~kg} / \mathrm{s}) \times W_{\text {net tubin uap }}(\mathrm{kJ} / \mathrm{kg})$

$W_{\text {net tubin uap }}(\mathrm{kJ} / \mathrm{kg})=W_{\text {turbin }}-W_{\text {pompa }}$

Dengan mengetahui dari kerja bersih turbin uap, maka dapat diekspresikan kerja bersih dalam $\mathrm{kW}$, yaitu :

$W_{\text {net }}=22.881 \mathrm{~kg} / \mathrm{s} \mathrm{x} 784 \mathrm{~kJ} / \mathrm{kg}$

$W_{\text {net }}=17938.704 \mathrm{~kW}$

Dari hasil tersebut, maka daya yang dihasilkan oleh turbin gas cukup memadai untuk menutupi daya yang telah direncanakan untuk turbin uap sebesar $12 \mathrm{MW}$, dimana daya yang dihasilkan oleh sistem pembangkit turbin uap sebesar 17.939 MW. Dengan mengetahui kemampuan turbin gas sebesar 2.06275 MW untuk setiap unitnya (8.251 MW untuk 4 unit

\section{KESIMPULAN}

Dalam penelitian yang telah penulis analisa pada siklus Pembangkit Listrik Tenaga Biomassa, maka dapat dituliskan beberapa kesimpulan sebagai berikut: Kerja per satuan massa siklus Brayton $360.592 \mathrm{~kJ} / \mathrm{kg}$, siklus $m=82372.73035 \mathrm{~kg} / \mathrm{h}$
$m=82372.73035 \mathrm{~kg} / \mathrm{h}: 3600 \mathrm{~s}$
$m=22.881 \mathrm{~kg} / \mathrm{s}$

bersih dari sistem pembangkit dalam bentuk $\mathrm{kW}$ adalah sebagai berikut :

$W_{\text {net }}=518.351 \mathrm{~kJ} / \mathrm{kg}-157.759 \mathrm{~kJ} / \mathrm{kg}$

$W_{\text {net }}=360.592 \mathrm{~kJ} / \mathrm{kg}$

$W_{\text {net }}=8.251 \mathrm{MW}$

membangkitkan pembangkit 2 MW). Pada turbin uap yang telah diketahui kondisi kinerjanya, maka dengan mengkalikan massa gas methan yang ada sebesar $22.881 \mathrm{~kg} / \mathrm{s}$ akan menghasilkan kinerja siklus turbin uap dengan daya dalam bentuk kWatt. Adapun hasil daya tersebut adalah sebagai berikut :

$W_{\text {net turbin uap }}=910 \mathrm{~kJ} / \mathrm{kg}-126 \mathrm{~kJ} / \mathrm{kg}$

$W_{\text {net turbin uap }}=784 \mathrm{~kJ} / \mathrm{kg}$

$W_{\text {net }}=17.939 \mathrm{MW}$

turbin gas) dan 17.939 MW untuk turbin uap, maka dalam pengoperasian untuk memenuhi daya sebesar 20 MW dapat dilakukan pengoperasian secara bergantian, sehingga dalam pemeliharaan, pemakaian bahan bakar, serta operasional dapat dilakukan lebih efektif dan efisien.

Rankine $784 \mathrm{~kJ} / \mathrm{kg}$, serta PLTGU adalah $505.64 \mathrm{~kJ} / \mathrm{kg}$. Efesiensi termal Siklus yang dipergunakan dalam perencanaan, yaitu : siklus Brayton menghasilkan effesiensi sebesar $30.1887 \%$, siklus Rankine sebesar $25.8831 \%$ 
dan siklus Brayton-Rankine (PLTGU) sebesar $58.1977 \%$.Turbin gas yang dipergunakan adalah 3 unit (dari 8.251 MW, serta 1 Unit

\section{DAFTAR PUSTAKA}

Ade Basyarat, 2006, Kajian Terhadap Penetapan Lokasi TPA Sampah Leuwinanggung - Kota Depok, Program Pasca Sarjana, Magister Teknik Pembangunan Wilayah dan Kota, Universitas Diponegoro, Semarang.

Ahmad Agus Setiawan, Suhono, M. Kholid Ridwan, Haryono Budi Santosa, Susetyo Haryo Putro, Yudi Utomo Imardjoko, 2008, Studi Awal Kebutuhan Energi Listrik Dan Potensi Pemanfaatan Sumber Energi Terbarukan Di Kabupaten Sleman Daerah Istimewa Yogyakarta, Jurusan Teknik Fisika, Fakultas Teknik, Universitas Gajah Mada

Dyos Santoso dan Hasan Basri, 2011, Analisis Eksergi Siklus Kombinasi Turbin GasUap Unit PLTGU Inderalaya, Fak. Teknik Univ. Sriwijaya, Prosiding Seminar Nasional A VoER ke-3; Palembang, 26-27 Oktober 2011

Eflita Yohana dan Ady Priambodo, 2012, Analisa Efesiensi Low Pressure HRSG (Heat Recovery Steam Generator) pada PLTGU PT. Indonesia Power UBP Semarang, Rotasi - Vol.14, No.1, Januari $2012: 7-9$

H.Muh. Syahrir Habiba; F. Cahyadi, Suryani; 2006, Analisis Efektifitas Sistem Pembangkit Listrik Tenaga Gas dan Uap (PLTGU) pada PT. Energi Sengkang, Program Studi Teknik Mesin Fakultas Teknik Universitas Islam Makassar, ILTEK, Volume I, Nomor 2, April 2006

Keppres No. 1 Tahun 2014, Pedoman Penyusunan Rencana Umum Energi Nasional (RUEN) dan Rencana Umum Energi Daerah (RUED), Jakarta
Turbin Gas untuk cadangan) dan 1 unit Turbin Uap sebesar 17.939 MW untuk memperoleh Daya $20 \mathrm{MW}$.

Kukuh Siwi Kuncoro, 2009, Studi Pembangunan Pembangkit Listrik Tenaga Sampah 10 MWe Di Kota Medan Ditinjau Dari Aspek Teknis, Ekonomi Dan Lingkungan, Institut Teknologi Sepuluh Nopember.

M.M. El-Wakil, 1988, Powerplant Technology, Mc Graw-Hill, Inc; International Edition.

Michael Hutagalong, 2007, Teknologi Pengolahan Sampah, http://majarimagazine.com

Murni Rahayu Purwaningsih, 2012, Analisis Biaya Manfaat Sosial Keberadaan Pembangkit Listrik Tenaga Sampah Gedebage bagi Masyarakat Sekitar, Jurnal Perencanaan Wilayah dan Kota, Vol. 23 No. 3, Desember 2012, pp. 225 -240 .

Nandi, 2005, Kajian Keberadaan Tempat Pembuangan Sampah (TPA) Leuwigajah dalam Konteks Tata Ruang, Jurnal "GEA" Jurusan Pendidikan Geografi, Vol. 5, Nomor 9, April 2005

Peraturan Presiden Republik Indonesia, No. 5 Tahun 2006

Safrizal, 2014, Distributed Generation Pembangkit Listrik Tenaga Sampah Kota (Pltsa) Type Incinerator Solusilistrik Alternatif Kota Medan, Program Studi Teknik Elektro, Fakultas Sains dan Teknologi, Universitas Islam Nahdlatul Ulama (Unisnu), Jepara, Prosiding Snatif Ke -1 Tahun 2014

Undang-Undang No.18 Tahun 2008, Pengelolaan Sampah

Yunus A Cengel, 2007, Michael A. Boles, Thermodynamics, Six Edition, Mc Graw Hill. 